\title{
HAMBATAN SUFISME TERHADAP PENDIDIKAN KOGNITIF DAN SUMBANGAN SUFISME TERHADAP PENDIDIKAN AFEKTIF
}

\author{
Oleh: \\ Akbarizan (Staf Pengajar FS' LAIN Suska) \\ dan Darmiyati Z. (Staf Pengajar FBS UNY)
}

\begin{abstract}
Abstrak
Penelitian ini bertujuan untuk mendapatkan gambaran yang jelas tentang: 1) hambatan sufisme terhadap pendidikan kognitif. dan 2) sumbangan sufisme terhadap pendidikan afektif. Penelitian ini merupakan penelitian kualitatif dan menggunakan prosedur analisis isi. Sumber data utama adalah kitab Al-Risalah al-Qusyairiyyah.

Sekurang-kurangnya ada tiga hal utama dalam sufisme yang menjadi penghambat pengembangan kemampuan kognitif, yaitu penghargaan yang terlalu tinggi kepada ilmu kasvaf daripada pengetahuan ilmiah empiris. pengutamaan perasaan (dzaug) dan pengalaman rohani daripada berpikir kritis. dan sistem pendidikan yang bersifat teacher centered. Selanjutnya, terdapat empat sumbangan sufisme bagi pendidikan afektif. yaitu berbagai potensi pengembangan dan pembinaan iman dan taqwa, potensi pendidikan budi pekerti, dan potensi metode pendidikan yang praktis.
\end{abstract}

Kata Kunci: sufisme, kognitif, afektif.

\section{Pendahuluan}

Pondok pesantren sebagai salah satu tiang penyangga pendidikan nasional yang menjadi pusat penyemaian dan penyebaran ilmu-ilmu keislaman dan ilmu-ilmu lainnya (periode modern), merupakan basis yang kokoh bagi dilaksanakannya praktik-praktik sufisme. Hal ini terbukti dengan banyaknya aliran-aliran tarekat atau suluk di pesantren-pesantren tersebut.

Komunitas pesantren yang terdiri dari para santri dan kyai merupakan suatu populasi yang membentuk suatu kelompok masyarakat. Kelompok masyarakat inilah yang disebut masyarakat sufi. Jadi. masyarakat sufi adalah kelompok sosial yang menjalankan doktrin-doktrin sufisme dalam aktivitas 
kehidupan, khususnya dalam proses pendidikan oleh kyai, pimpinan pondok pesantren.

Sufisme (tasawuf) adalah salah satu aliran (mazhab) atau aspek pemikiran Islam yang sering dikaji ilmuwan. Sufisme juga menarik perhatikan "nonilmuwan" seperti kaum awam, birokrat, dan teknokrat. Mereka membutuhkan sesuatu yang bisa memuaskan akal budinya, menenteramkan jiwanya, memulihkan kepercanyaan dirinya dan sekaligus mengembalikan keutuhan kepribadian, yang nyaris punah karena dorongan kehidupan materialistis dalam konflik ideologis dewasa ini.

Di samping itu, masyarakat sufi memiliki lembaga-lembaga pendidikan yang terkenal di dunia Islam pada masanya. Sufisme juga telah mengembangkan suatu sistem pendidikan yang khas yang persoalan spiritual mendapatkan tempat penting dan dominan. Lembaga-lembaga sufi ini merupakan fenomena besar yang tidak mungkin diabaikan dalam kajian sejarah pendidikan Islam (Asari, 1994:89). Seorang tokoh sufi, al-Taftazani dalam tulisannya menyebutkan beberapa sumbangan untuk pendidikan di antaranya tentang tujuan, metode dan azas pendidikan yang dikembangkan dalam sufisme (1985:137).

Menurut Djohan Effendi (1993), agama dan keberagaman makin menghajatkan peranan sufisme karena dalam sufismelah terletak esensi keberagamaan dan dalam sufismelah terdapat masa depan agama. Bila dihubungkan dengan kondisi Indonesia sekarang, dengan pendidikan nasional masih mencari bentuk yang tepat untuk dapat mengembangkan aspek kognitif, afektif dan psikomotorik maka pola perilaku pendidikan sufisme dapat menjadi pertimbangan alternatif bagi pengembangan pendidikan Indonesia. Hal ini disebabkan oleh kenyataan bahwa pesantren merupakan tiang penyangga pendidikan nasional yang sudah berakar di Indonesia dan menjadi basis kuat dilaksanakannya doktrin-doktrin sufisme.

Masalahnya, sudah tepat dan relevankah sistem, metode, pola perilaku atau lembaga pendidikan masyarakat sufi itu dengan era modern sekarang? Bagaimana pula dengan kontribusi dan potensi sufisme bagi pendidikan?

Beberapa doktrin sufisme dianggap menghambat pengembangan ilmu pengetahuan ilmiah empiris. Simuh (1996-271) menyatakan bahwa sufisme mempunyai andil besar bagi redupnya penalaran ilmiah umat. Hal ini menurutnya dikarenakan sufisme lebih mengutamakan perkembangan perasaan (dzauq) dan kurang menggarap pertumbuhan daya kritis dan penalaran. 
Adanya keyakinan bahwa ilmu kasyaf lebih tinggi dan berharga daripada pengetahuan ilmiah empiris, dan sistem pendidikan yang bersifat guruisme (teacher-centered), yang kepatuhan dan penerimaan bulat-bulat dituntut dari murid, pada akhirnya akan menutup dan mematikan daya kreativitas dan aktivitas siswa.

Dari uraian di atas dapat dikatakan bahwa sufisme di samping memiliki potensi dan kontribusi bagi pendidikan juga memiliki sisi negatif bagi pengembangan intelektual. Penulis ingin meneliti secara kritis sisi positif dan negatif pola perilaku sufisme sebagai suatu aliran pendidikan.

\section{Pembahasan}

Sufisme yang pada mulanya adalah suatu bentuk aliran keagamaan yang bersifat pribadi, lalu berkembang menjadi aliran keagamaan yang bersifat kolektif. Oleh karena itu, sufisme lalu membentuk halaqah (lingkaran) muridmurid di sekeliling guru yang diakui untuk mendapatkan pengajaran dan pendidikan keagamaan yang bersifat sufistik. Kemudian, bentuk pendidikan ini tumbuh lagi menjadi sistem guru (mursyid, syeikh) dan murid (salik), yang merupakan sekolah-sekolah bebas untuk mendapatkan pelajaran dan bimbingan.

Sufisme dapat dikatakan memiliki lembaga pendidikan tersendiri dan mengembangkan sistem pendidikan yang khas. Persoalan spiritual dalam sufisme selalu mendapatkan tempat yang dominan. Jalan rohani yang dipergunakan dalam sufisme merupakan sebuah metode praktis yang amat efektif untuk mencapai tujuan, khususnya pendidikan iman, dan taqwa, serta budi pekerti.

Sufisme yang dikembangkan oleh Imam Al-Qusyairi dalam kitabnya $\mathrm{Al}$ Risalah Al-Qusyairiyah memiliki karakteristik yang lebih religius. Sufisme $A l$ Risalah tidak berkarakteristik filosofis penuh. Ia lebih bercorak praktis karena aspek moral dan spritual religius mendapatkan tempat yang lebih dominan. Sufisme $A l$-Risalah berupaya membawa sufisme ke arah aliran sunni. $A l$ Risalah juga memiliki beberapa pemikiran tentang pendidikan yang perlu menjadi pertimbangan dalam mencapai format pendidikan yang tepat bagi Indonesia.

Sebagaimana sufisme secara umum, di dalam Al-Risalah terdapat beberapa pemikiran yang tidak relevan atau cocok. bahkan merugikan bagi pendidikan Indonesia khususnya sisi negatif bagi pengembangan aspek 
kognitif. Di samping itu, sufisme dalam al-Risalah mempunyai potensi dan kontribusi yang baik bagi pendidikan. Ketidakrelevansian sufisme terletak pada pengembangan aspek kognitif. Adapun potensi dan kontribusinya terletak pada pengembangan aspek afektif.

Ada tiga hal utama dalam sufisme yang dapat menjadi penghambat bagi pengembangan kognisi, dalam hal ini daya kritis dan kreatif, penalaran ilmiah, dan penelitian empiris anak didik, yaitu sebagai berikut.

1. Penghargaan yang terlalu tinggi kepada ilmu kasyaf dan sejenisnya daripada ilmu empiris ilmiah. Hal ini terlihat dari ungkapan-ungkapan sebagai berikut.

"Sang arif lebih besar dari pada apa yang dikatakannya, dan sang alim lebih kecil daripada apa yang dikatakannya" (Al-Qusyairi, tt: 316)

"Seseorang yang melihat dengan cahaya firasat berarti melihat dengan cahaya Allah, inti pengetahuannya datang dari Allah, tidak bercampur dengan kealpaan ataupun kelalaian" (Al-Qusyairi, tt: 231).

2. Pengutamaan perasaan (dzauq) dan pengalaman rohani daripada berpikir kritis. Hal ini terlihat dari ungkapan-ungkapan berikut.

"Seorang murid (sufi) yang tulus dan jujur tidak membutuhkan ilmu pengetahuan ulama" (Al-Qusyairi, tt: 204).

"Manakala Allah menghendaki kebaikan bagi seorang murid, Allah akan membawanya ke lingkungan "sufiyah" dan menjauhkannya dari lingkungan "cendekiawan" (Al-Qusyairi, tt: 203).

"Barangsiapa yang mengatakan "kenapa" (mempertanyakan sesuatu kepada gurunya), maka ia tidak akan berhasil selama-lamanya" (AlQusyairi, tt: 334).

3. Sistem pendidikan yang bersifat teacher centered (guruisme).Hal ini terlihat dari ungkapan-ungkapan berikut. 
"Guru wajib dihormati dan tidak boleh dibantah atau berbeda dengan guru dan selalu berusaha keras jangan sampai guru tidak menyukainya" (Al-Qusyairi, tt: 383).

"Guru-guru adalah manusia yang termulia dan terhormat, dan yang paling mengetahui" (Al-Qusyairi, tt: 379).

Penghargaan terlalu tinggi kepada ilmu kasyaf dan pengutamaan perasaan, secara otomatis melumpuhkan atau meredupkan penggunaan rasio (nalar) serta penelitian ilmiah. Untuk pengembangan pengetahuan ilmiah dituntut penalaran ilmiah bukan intuisi kasyafiyah, dan menuntut pikiran yang sistematis runtut yang sesuai dengan aturan-aturan ilmu logika, bukan intuisi meski terkondisi sekalipun. Pengembangan intelektual dan pengetahuan ilmiah menuntut murid yang selalu berpikir kritis, tidak meyakininya secara an sich. sedangkan sistem pendidikan yang bersifat teacher centered (guruisme), menutup kesempatan bagi murid untuk berpikir, belajar sendiri dan belajar mandiri. Sistem pendidikan yang bersifat teacher centered tidak dapat mengembangkan secara penuh keaktifan dan daya kritis murid, sebagai faktor yang penting untuk pengembangan aspek kognitif.

Pengembangan kognitif atau ilmu pasti berada pada idealisasi teoretik, moralistik, hingga transendental secara reflektif. Operasionalisasinya adalah pertama lewat telaah empirik, lewat abstraksi, lewat penjabaran induksi deduksi, berangkat dari dasar teoretik atau sistematika ilmu, dalam tampilan inklusif dan dalam kalkulus kebenaran probabilistik. Model pengembangan seperti ini meletakkan kebenaran penghayatan spiritual sufistik atau transsendental Ilahiyah menjadi petunjuk dan acuan. Model ini merupakan alternatif yang terbaik dengan ia memperkenalkan kebenaran berpikir monistik multifaset (Noeng Muhadjir, 2001:179).

Adapun kontribusi sufisme al-Risalah terletak pada aspek pendidikan afektif, yang meliputi berbagai potensi dalam pendidikan dan pembinaan iman dan taqwa pendidikan budi pekerti, perkembangan psikologi pendidikan, dan penggunaan metode pendidikan yang cukup praktis. Sistem pendidikan dan doktrin dalam sufisme sangat mendukung bagi pendalaman rasa beragama (spritualitas) dan keyakinan, mampu memantapkan dan menghidupkan iman dan taqwa, dan mampu menanamkan budi pekerti yang mulia bagi murid. Sufisme mempunyai ide-ide mengenai kemampuan inheren dalam jiwa 
manusia dengan faktualitasnya memperhitungkan berapa jauh kelemahan dan kemampuannya. Ide-ide ini merupakan sumbangan yang baik bagi psikologi pendidikan di era modern. Jalan rohani (maqamat atau tahapan-tahapan) yang terdapat dalam sufisme secara substantif menjadi metode praktis untuk membimbing dan mendidik murid dalam cara berpikir, merasa, dan bertindak. Metode ini antara lain metode ibadah, teladan, latihan, pembiasaan dan cerita.

\section{Kesimpulan dan Saran}

Berdasarkan pembahasan yang dilakukan, dapat disimpulkan bahwa sufisme berkaitan dengan pendidikan dalam dua aspek, yaitu aspek kognitif dan afektif. Terhadap aspek kognitif, sufisme tidak dapat diandalkan atau kurang relevan dengan pendidikan modern, bahkan sufisme dapat meredupkan kemampuan intelektual manusia. Terhadap aspek afektif, sufisme justru memberikan sumbangan yang berarti, karena sufisme mendukung bagi pendalaman keyakinan, iman, dan taqwa, serta pembinaan budi pekerti yang mulia. sebagai berikut.

Dari pembahasan dan penelitian ini dapat disarankan beberapa hal, yaitu

1. Pengkajian lebih lanjut tentang aplikasi operasionalisasi kontribusi sufisme dalam penanaman budi pekerti.

2. Pengkajian tentang bagaimana konstribusi sufisme diaktualisasikan di dalam proses pendidikan di Indonesia.

3. Pengkajian tentang bagaimana hambatan sufisme itu dapat diminimalisasi dalam proses pendidikan di Indonesia.

Adapun bagi praktisi pendidikan disarankan untuk dapat menjadikan penelitian ini sebagai pertimbangan dalam:

1. membangun pendidikan yang menyeimbangkan aspek kognitif dengan aspek afektif sehingga dapat membentuk jalinan yang harmonis dalam pribadi individu,

2. menanamkan nilai-nilai budi pekerti dengan pendekatan perasaan dan hati nurani bukan hanya memperkenalkan nilai-nilai budi pekerti dengan rasio dan logika. 


\section{Daftar Pustaka}

Effendi, Djohan. (1993). Sufisme dan Masa Depan Agama. Jakarta: Pustaka Firdaus.

Muhadjir, Noeng. (2000). Metodologi Penelitian Kualitatif. Yogyakarta: Rake Sarasin Rake Sarasin.

Qusyairi, Abd al-Karim ibn Hawazin al. (tt). Al-Risalh al-Qusyiriyyah. Kairo: Al-Manar.

Simuh. (1996). Tasawwuf dan Perkembangannya dalam Islam. Jakarta: Raja Grafindo Persada.

. (1995). Sufisme Jawa. Yogyakarta: Benteng Budaya. 